-
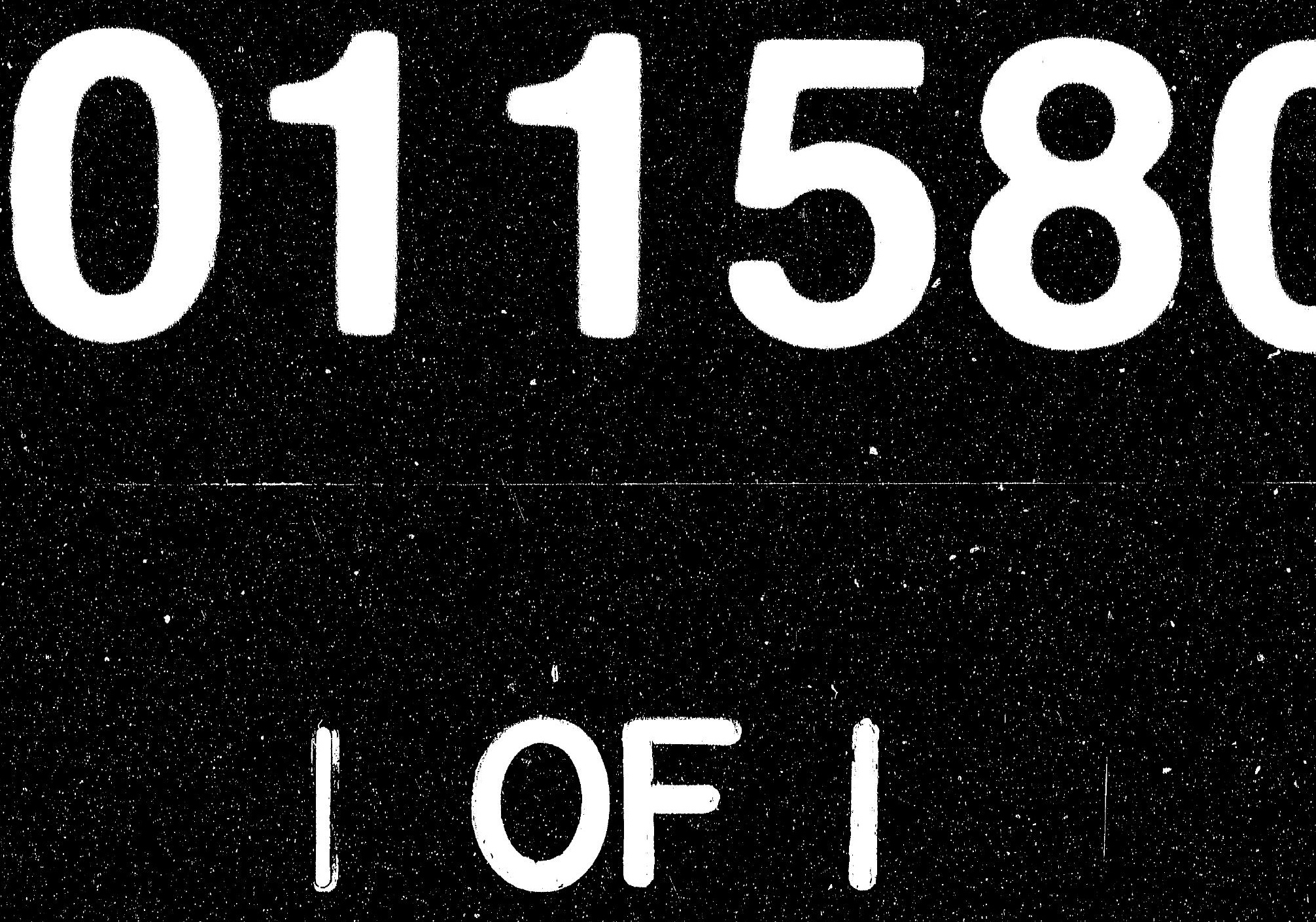

-

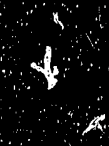

1,2
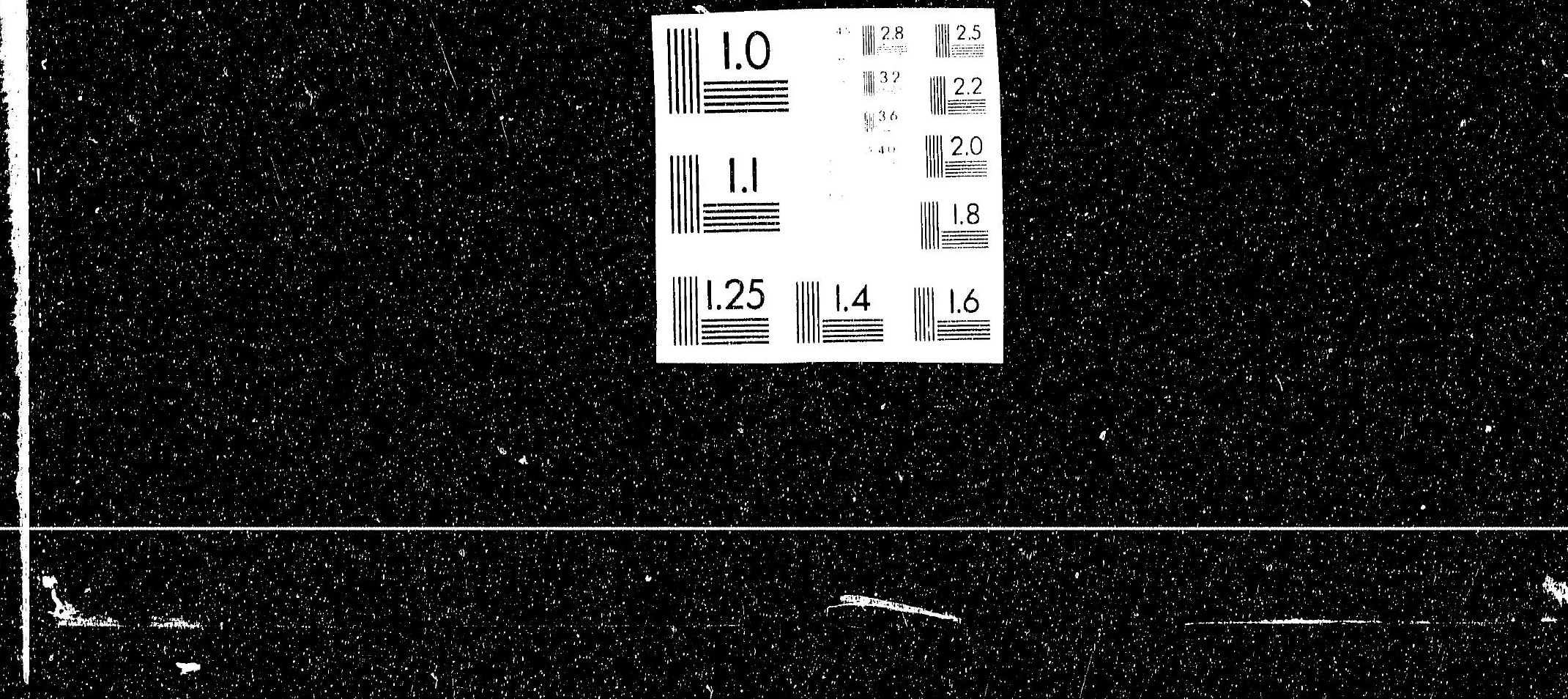

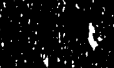

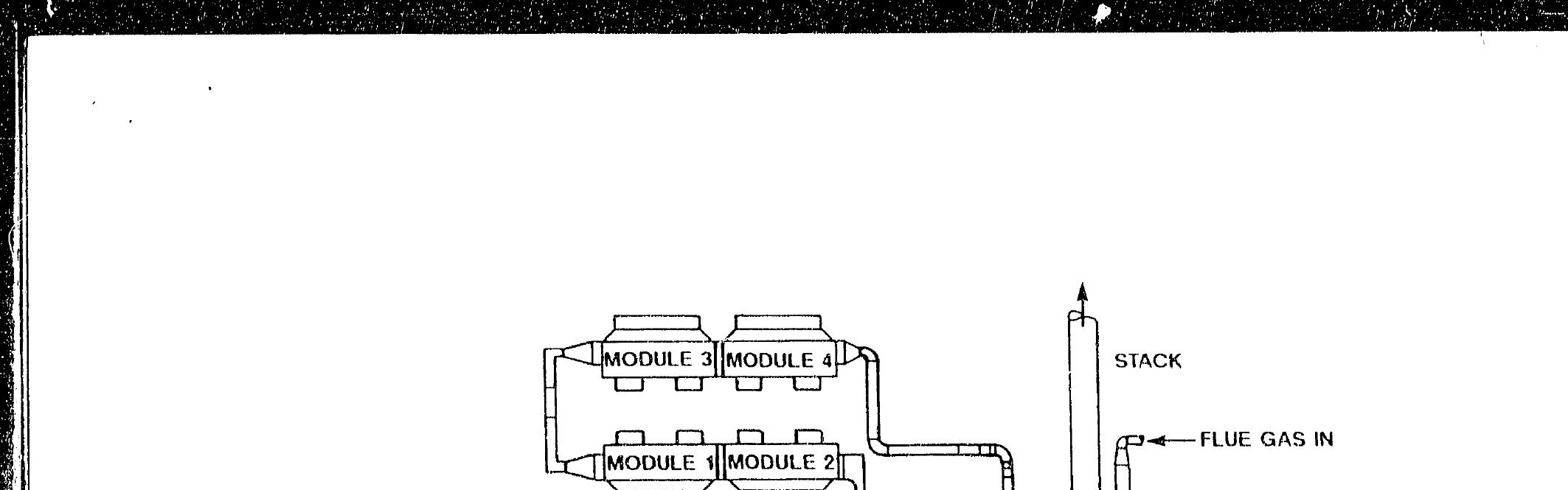




$$
\text { DOE/PC/88654--T4 }
$$

DOE/PC/88654--T4

DRAFT

DE92 011580

\title{
COMBUSTION CHARACTERIZATION OF
}

BENEFICIATED COALBASED FUELS

QUARTERLY REPORT NO. 3 FOR THE PERIOD NOVEMBER 1989 TO JANUARY 1990

PREPARED BY

COMBUSTION ENGINEERING, INC.

1000 PROSPECT HILL ROAD

WINDSOR, CT. 06095

PROJECT MANAGER

MICHAEL J. HARGROVE

MARCH 1990

PREPARED FOR

\author{
US DEPARTMENT OF ENERGY \\ PITTSBURGH ENERGY TECHNOLOGY CENTER \\ UNDER CONTRACT NO. DE-AC 22-89 PC 88654 \\ DISCLAIMER
}

\begin{abstract}
This report was prepared as an account of work sponsored by an agency of the United States Government. Neither the United States Government nor any agency thereof, nor any of their employees, makes any warranty, express or implied, or assumes any legal liability or responsibility for the accuracy, completeness, or usefulness of any information, apparatus, product, or process disclosed, or represents that its use would not infringe privately owned rights. Reference herein to any specific commercial product, process, or service by trade name, trademark, manufacturer, or otherwise does not necessarily constitute or imply its endorsement, recommendation, or favoring by the United States Government or any agency thereof. The views and opinions of authors expressed herein do not necessarily state or reflect those of the United States Government or any agency thereof.
\end{abstract}
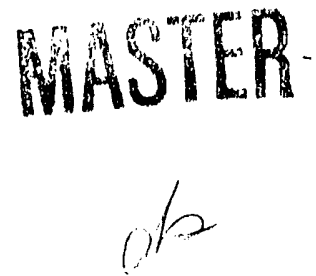


\section{DISCLAIMER}

This report was prepared as an account of work sponsored by the United States Government. Neither the United States nor the United States Department of Energy, nor Combustion Engineering, Inc., nor any of their employees, subcontractors, suppliers, or vendors makes any warranty, express or implied, or assumes any legal liability or responsibility for the accuracy, completeness, or uscfulness of any information, apparatus, product, or process disclosed, or represents that its use would not infringe privately owned rights. Reference herein to any specific commercial product, process, or service by trade name, mark, manufacturer, or otherwise, does not necessarily constitute or imply its endorsement, recommendation, or favoring by the United States Government or any agency thereof. The views and opinions of authors expressed herein do not necessarily state or reflect those of the United States Government or any agency thereof.

\section{ACKNOWLEDGEMENTS}

Contributors to this report include O. K. Chow, B. F. Griffith, and N. Y. Nsakala of Combustion Enginecring, Inc.; and S. A. Benson, J. P. Hurley, and C. J. Zygarlicke of the University of North Dakota Encrgy Environmental Research Center. 


\section{QUARTERLY REPORT}

TABLE OF CONTENTS

OBJECTIVE AND SCOPE

SUMMARY 2

TASK 1 - FUEL PREPARATION 3

TASK 2 - BENCH SCALE TEST

TASK 3 - PILOT-SCALE TESTS 10

TASK 4 - SCALE-UP TESTS 24

TASK 5 - TECHNO-ECONOMIC EVALUATION 24

WORK PLANNED FOR NEXT QUARTER 25 


\section{OBJECTIVE AND SCOPE}

This three-year rescarch project at Combustion Enginecring, Inc. (CE), will assess the potential economic and cnvironmental benefits derived from coal beneficiation by various advanced cleaning processes. The objectives of this program include the development of a detailed generic engineering data base, comprised of fuel combustion and ash performance data on beneficiated coal-based fuels (BCFs), which is needed to permit broad application. This technical data base will provide detailed information on fundamental fuel properties influencing combustion and mineral matter behavior as well as quantitative performance data on combustion, ash deposition, ash erosion, particulate collection, and gaseous and particulate emissions. Program objectives also address the application of this technical data base to predict performance impacts associated with firing BCFs in various commercial boiler designs as well as assessment of the economic implications of BCF utilization. Additionally, demonstration of this technology, with respect to large-scale fuel preparation, firing equipment operation, fuel performance, environmental impacts, and verification of prediction methodology, will be provided during ficld testing.

Twenty fuels will be characterized during the three-ycar base program: three feed coals, fifteen BCFs, and two conventionally cleaned coals for the field test. Approximately nine BCFs will be in dry ultra fine coal (DUC) form, and six BCFs will be in coal-water fuel (CWF) form. Up to 25 additional BCFs would be characterized during optional project supplements. 


\section{SUMMARY}

During the fourth quarter of 1989 , the following technical progress was made.

- Evaluated ignitibility and reactivity chararteristics of the Illinois and Upper Freeport beneficiatcd products, including flammability indices, TGA, and BET surface areas.

- Completed pilot-scale combustion and ash deposition tests of the Illinois No. 6 microbubble product in standard pulverized form.

- Continued analyses of as-fired fuels and resulting ash deposits. 


\section{TASK 1 - FUEL PREPARATION}

Bencficiated coals (BCs) and feed coals are acquired from other DOE projects and shipped to CE. These fucls are then processed into either a dry pulverized coal form by CE or a coal-water fucl (CWF) form using OXCE Fucl Company technology. The feed coals are fired as standard grind (70\% minus 200 mesh) pulverized coal (PC), while the dry beneficiated fuels are generally dry ultra fine coal (DUC).

Six twenty-ton batches of test fucls had been stored at PETC in sealed, inerted drums from the last quarter of 1987 until the summer of 1989 . These fuels included:

1. Illinois No. 6 feed coal

2. Pittsburgh No. 8 fced coal

3. Upper Freeport feed coal

4. Illinois No. 6 microbubble flotation product

5. Pittsburgh No. 8 microbubble flotation product

6. Upper Freeport microbubble flotation product

The three feed coals were tested at CE during the previous two quarters. The remaining Upper Freeport feed coal was shipped to MIT for their combustion tests, after being pulverized in the FPTF bowl mill to an approximate fineness of $75-89 \%$ through 200 mesh. The air drying of the Illinois \#6 and Upper Freeport microbubble products was completed using drying trays in a heated room. The Illinois \#6 dried microbubble product was fired in the FPTF in a dry pulverized form, after the final drying and pulverization was done in the FPTF bowl mill.

The Upper Freeport dried microbubble product will be made into CWF. Manufacturing of the CWF is scheduled for the first part of February with shipment of the CWF to MIT scheduled for mid-February.

Discussions were held at PETC to determine what the next BCF's would be. It was decided that the BCF's would come from the spherical agglomeration process to be performed at Homer City. The first BCF to be processed will be the Illinois \#6. The first agglomerates are scheduled to be delivered to CE in mid-to-late February. 


\section{TASK 2 - BENCH-SCALE TESTS}

All test fucls are fully characterized using various standard and advanced analytical techniques. These tests evaluate the impacts of parent coal properties and beneficiation processes on the resulting BCF's qualities.

A few sclected fucls are tested in a laminar flow drop tube furnace to determine fly ash particle size and chemical composition. Results include mineral matter measurements and modeling of fly ash history.

A swirl-stabilized, entrained flow reactor is used to characterize the surface compositions and the states of ash particles formed during combustion. Deposition rates on a target are determined, and the size and compositions of the deposits from different fuels are compared.

\section{Drop Tube Furnace System-1 (DTFS-1) Combustion Tests at CE}

Work during this quarter focused on evaluating the effect of particle size of beneficiated coal-based products (microbubble flotation products (MFPs) from Upper Freeport and Illinois No. 6 coals and spherical oil agglomeration product (SOAP) from lllinois No. 6 coal) on reactivity characteristics. TGA and BET measurements of chars prepared from these fuels were used as reactivity characterization parameters. A comparison of these results with those reported previously on the parent feed coals shows the effects of both fuel nature (i.e., parent fecd coal vs BCF) and particle size ( $200 \times 400$ mesh vs $325 \times 0$ mesh) on a given char reactivity.

CE normally conducts TGA and BET tests on $200 \times 400$ mesh char samples. The rationale for also including $325 \times 0$ mesh char samples in this study is that the benefication processes produce, by design, very fine products (e.g., 73 percent minus 325 mesh and 87 percent minus 325 mesh for Upper Frecport and Illinois No. 6 MFPs, respectively), as shown immediately bclow:

\section{Screen Size, X (micron)}

1180

600

300

150

75

45

\begin{tabular}{cc}
\multicolumn{2}{c}{ Weight Percent Greater than X } \\
\cline { 2 - 2 } (Upper Freeport MFP) & (Illinois No. 6 MFP) \\
0.1 & - \\
0.2 & 0.1 \\
0.6 & 0.4 \\
5.0 & 3.3 \\
19.5 & 8.6 \\
27.5 & 12.7
\end{tabular}

The TGA and BET test procedures entailed pyrolyzing 200x400-mesh and 325x0 mesh size fractions of BCF products in the DTFS-1 (Figure 2.2.1) in nitrogen atmosphere at $2650^{\circ} \mathrm{F}$ to drive off the volatile matter, and subjecting the resulting chars, sized to $200 \times 400$ and $325 \times 0$ mesh, respectivcly, to TGA and BET measurements in air at $700^{\circ} \mathrm{C}$ and nitrogen at $-196^{\circ} \mathrm{C}$, respectively. These procedures were depicted schematically in the December, 1989 , quarterly report.

The TGA results from this study are presented in Figures 2.2.2 to 2.2.4, and the BET data are shown below:

$\underline{\text { Parent Fuel }}$

Upper Frecport Coal

Upper Frecport Microbubble Product

Illinois No. 6 Coal

Illinois No. 6 Microbubble Product

Illinois No. 6 Oil Agglomeration Product

Pittsburgh No. 8 Coal

\begin{tabular}{cc} 
BET Surfacc Al . of Char, $\mathrm{m}^{2} / \mathrm{g}$ (daf) \\
\hline (200x400 mesh) & $(325 \times 0$ mesh) \\
23.6 & 28.8 \\
17.8 & 32.1 \\
33.1 & 32.5 \\
31.0 & 39.4 \\
35.9 & 48.6 \\
29.3 & 49.8
\end{tabular}

$-4-$ 


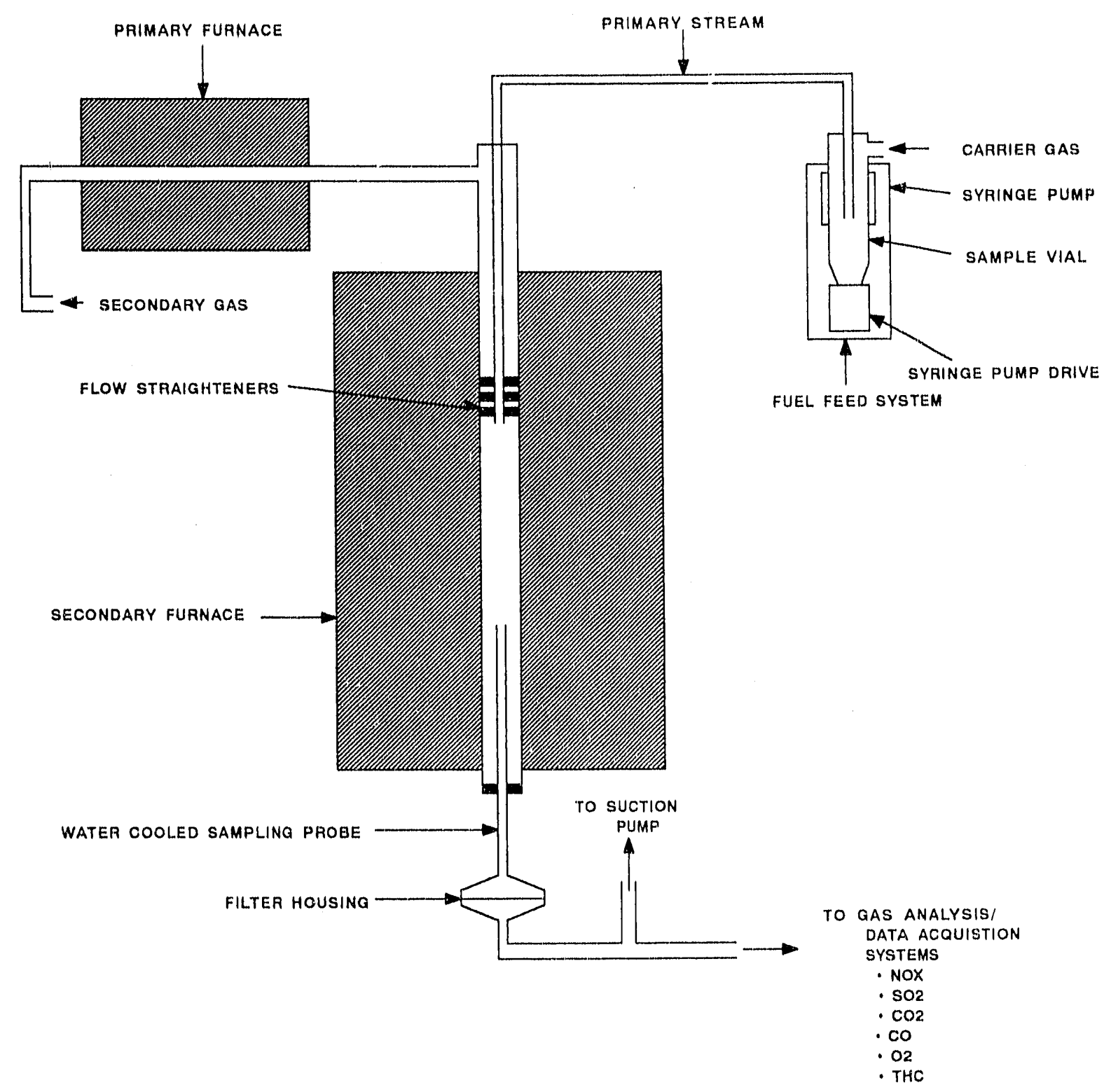

Figure 2.2.1 Schematic of Drop Tube Furnace System (DTFS-1) 

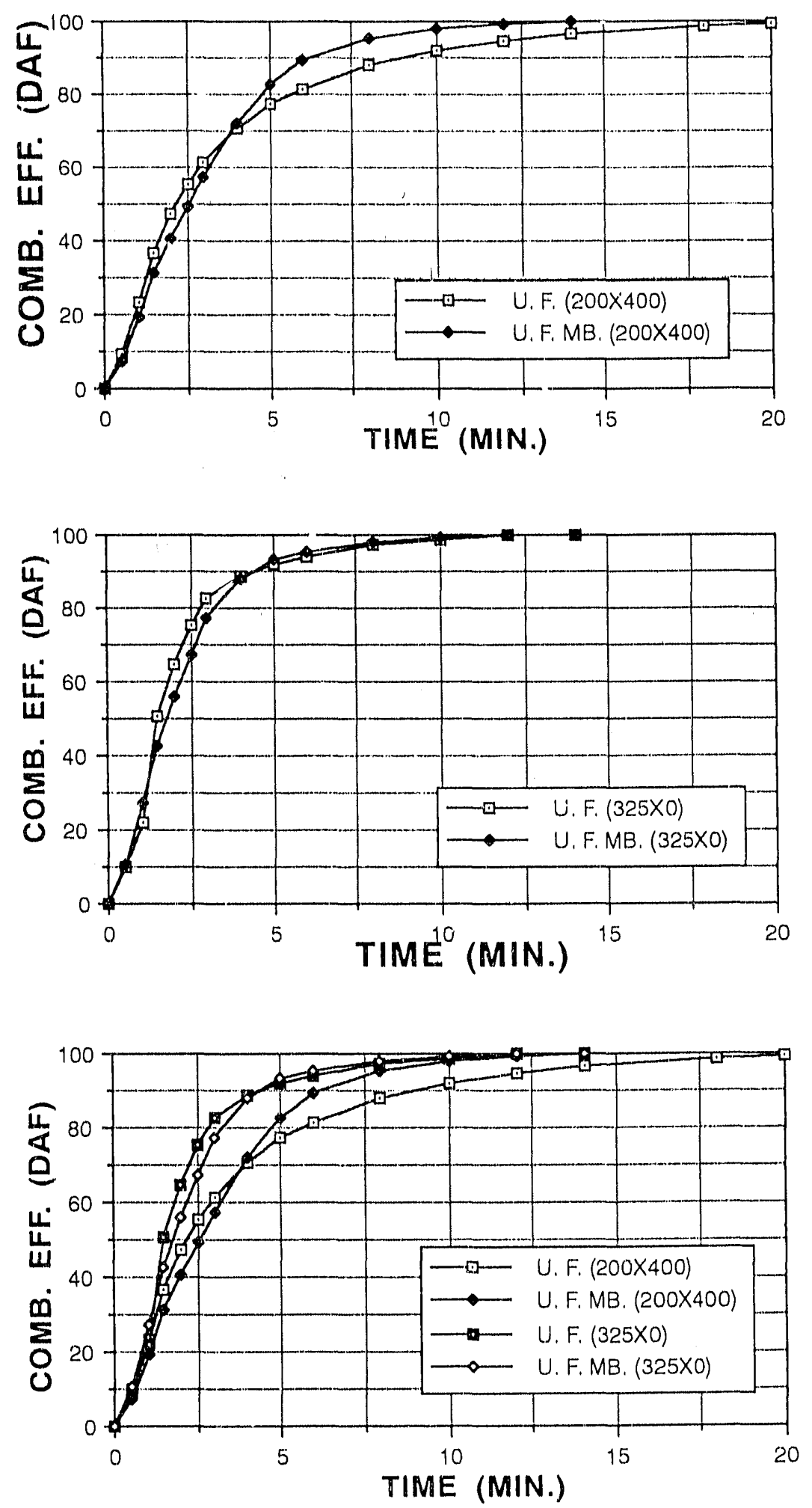

FIG. 2.2.2 TGA BURN-OFF CURVES IN AIR AT $700^{\circ} \mathrm{C}$ 

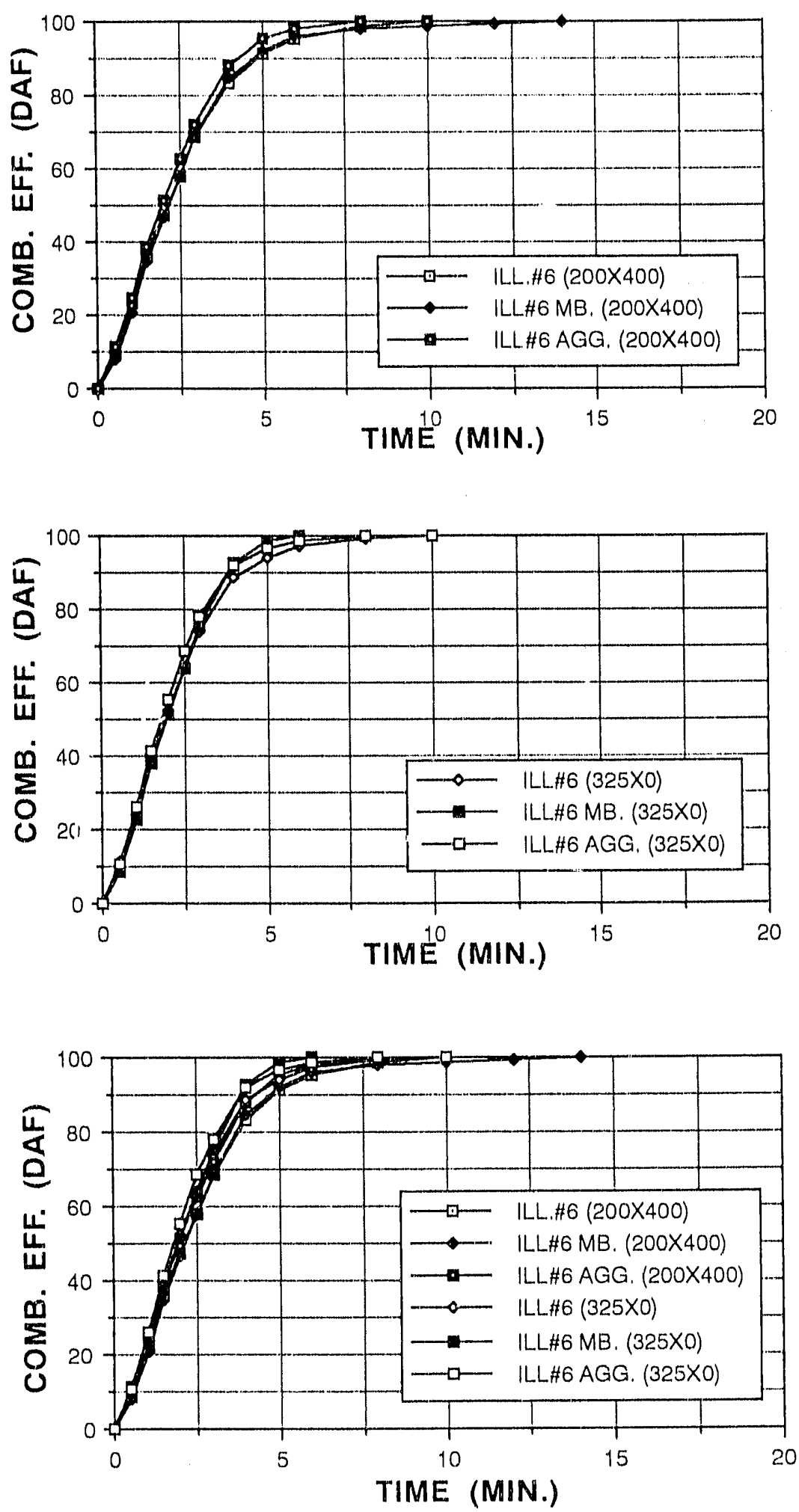

FIG. 2.2.3 TGA BURN-OFF CURVES IN AIR AT $700^{\circ} \mathrm{C}$ 

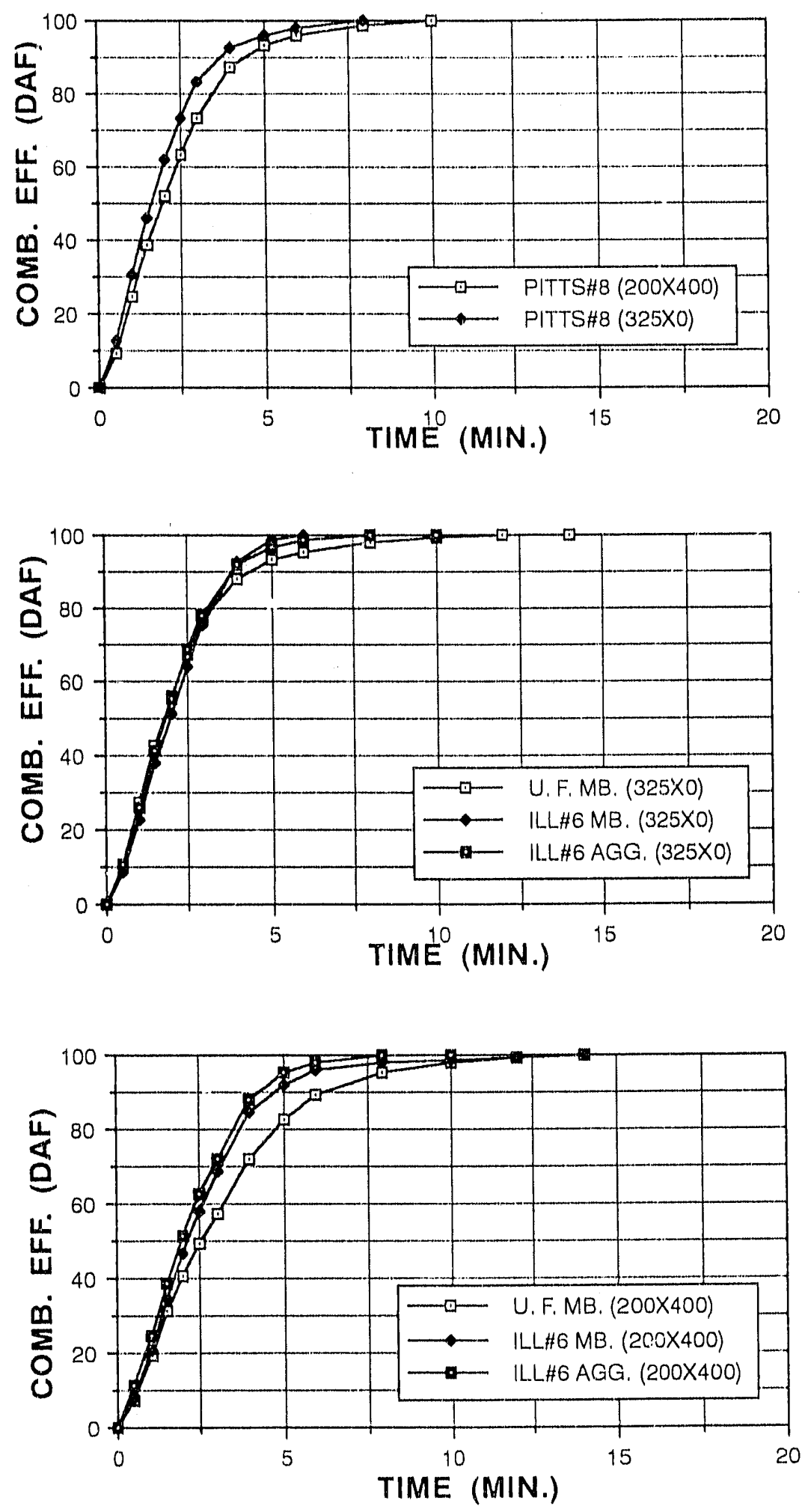

FIG. 2.2.4 TGA BURN-OFF CURVES IN AIR AT $700^{\circ} \mathrm{C}$ 
The TGA burn-off curves indicate that: (1) the microbubble coal cleaning process did not adversely affect the reactivitics of Illinois No. 6 and Upper Frecport coal chars; (2) the oil agglomeration process also did not adversely affect the reactivity of the Illinois No. 6 coal char; and (3) the impact of particle size on reactivity is more pronounced for the least reactive coal char (i.e., the one prepared from the Upper Freeport coal). The BET specific pore surface areas are generally in support of the TGA burn-off curve results.

Inasmuch as char burnout, rather than volatile matter release and burnout, constitutes the rate determining step in the overall scheme of pulverized coal combustion, it appears, based on these preliminary results, that the microbubble and oil agglomeration cleaning processes did not adversely affect the carbon burnout properties of the Upper Frecport and Illinois No. 6 feed coals. Future activitics on combustion kinetic studies (Task 2.2) and boiler modeling cvaluations (Task 5) will enable CE to quantitatively evaluate the effects of each coal clcaning process on the BCFs' burning characteristics. 


\section{TASK 3 - PILOT-SCALE TESTING}

This task includes burner tests in MIT's Combustion Research Facility and boiler performance tests in CE's Fireside Performance Test Facility. To date, combustion tests have been carried out in CE's Fireside Performance Test Facility (FPTF) with lllinois No. 6, Pittsburgh No. 8 and Upper Freeport feed coals and Illinois No. 6 microbubble flotation products, to evaluate their relative combustion characteristics, furnace wall slagging, convection pass fouling, fly ash erosion and electrostatic precipitator performance. Deposit samples generated from these fuels were sent to the University of North Dakota Energy and Environmental Research Center (UNDEERC) for detailed analyses. Most of the test data from the Illinois No. 6 feed coal and its corresponding microbibble flotation product have been reduced and are discussed in this report.

\subsection{Atomization, Combustion, and Emissions Tests - MIT}

Activities under this task were mostly facility preparation during this reporting period. The MIT Combustion Research Facility (CRF) is scheduled to test a coal-water fucl prepared from the Upper Frecport microbubble flotation product in February, 1990.

\subsection{Combustion Performance Tests - CE}

Combustion tests were completed with the Illinois No. 6 microbubble flotation product in the FPTF (Figure 3.2.1). It was tested as a dry, microfine pulverized fuel at a single firing rate $\left(4 \times 10^{6} \mathrm{Btu} / \mathrm{h}\right)$, with 20 percent excess air and at two furnace gas temperatures $\left(3030^{\circ} \mathrm{F}\right.$ and $\left.2960^{\circ} \mathrm{F}\right)$. These temperatures were achieved by varying the secondary air preheat. The test duration was 24 hours for each of the test run conditions. Figure 3.2.2 shows the temperature-time profile in the FPTF during these tests.

\section{Relative Combustion Characterization}

Good stable flame was obtained in the FFTF during the Illinois No. 6 MFP tests. Analysis of the fly ash samples indicated that the carbon content was very low, and the calculated carbon conversion efficiencies were greater than 99.9 percent. These results were similar to those obtained from the Illinois No. 6 feed coal tested in the FPTF under the same test conditions. The analyses of the MFP and feed coal are shown in Table 1.

\section{Furnace Slagging Characterization}

Furnace slagging was characterized by assessing the ease of deposit removal, deposit interface with heat transfer, deposit interference with heat transfer, deposit buildup rate, and the physical and chemical characteristics of the waterwall deposits. The ease of deposit removal, or response to soot blower cleaning, was the primary criterion used in determining the slagging potential of a test fuel. Results showed that a fused layer of deposits was formed ou the waterwall panels during each test run conducted at $3030^{\circ} \mathrm{F}$ and $2960^{\circ} \mathrm{F}$ furnace gas temperatures. The fused layer remained very thin $(0.49 \mathrm{~mm})$ throughout the two test runs. Consequently, the waterwall heat flux remained relatively high and constant after an initial heat flux reduction (Figure 3.2.3). The wall blower was not effective in removing these thin deposits at $3030^{\circ} \mathrm{F}$ and only partially effective at $2960^{\circ} \mathrm{F}$ furnace gas temperature. The critical furnace temperature where deposits are still cleanable by commercial wall blowers was therefore established at below $2960^{\circ} \mathrm{F}$.

A comparison of the furnace slagging characteristics between Illinois No. 6 feed and MFP is provided in Table 2. In general, at the same firing rate and similar gas temperature range, the MFP resulted in a higher average waterwall heat flux than that of the feed coal $\left(73,114 \mathrm{Btu} / \mathrm{h} \cdot \mathrm{ft}^{2}\right.$ vs $\left.65,460 \mathrm{Btu} / \mathrm{h}-\mathrm{ft}^{2}\right)$. This appeared to be due to the thinner deposits produced from the MFP than from the feed coal $(0.49 \mathrm{~mm}$ vs $2.78 \mathrm{~mm})$. However, waterwall deposit cleanability did not improve with the MFP. The critical furnace gas temperature remained at the same furnace temperature range. 


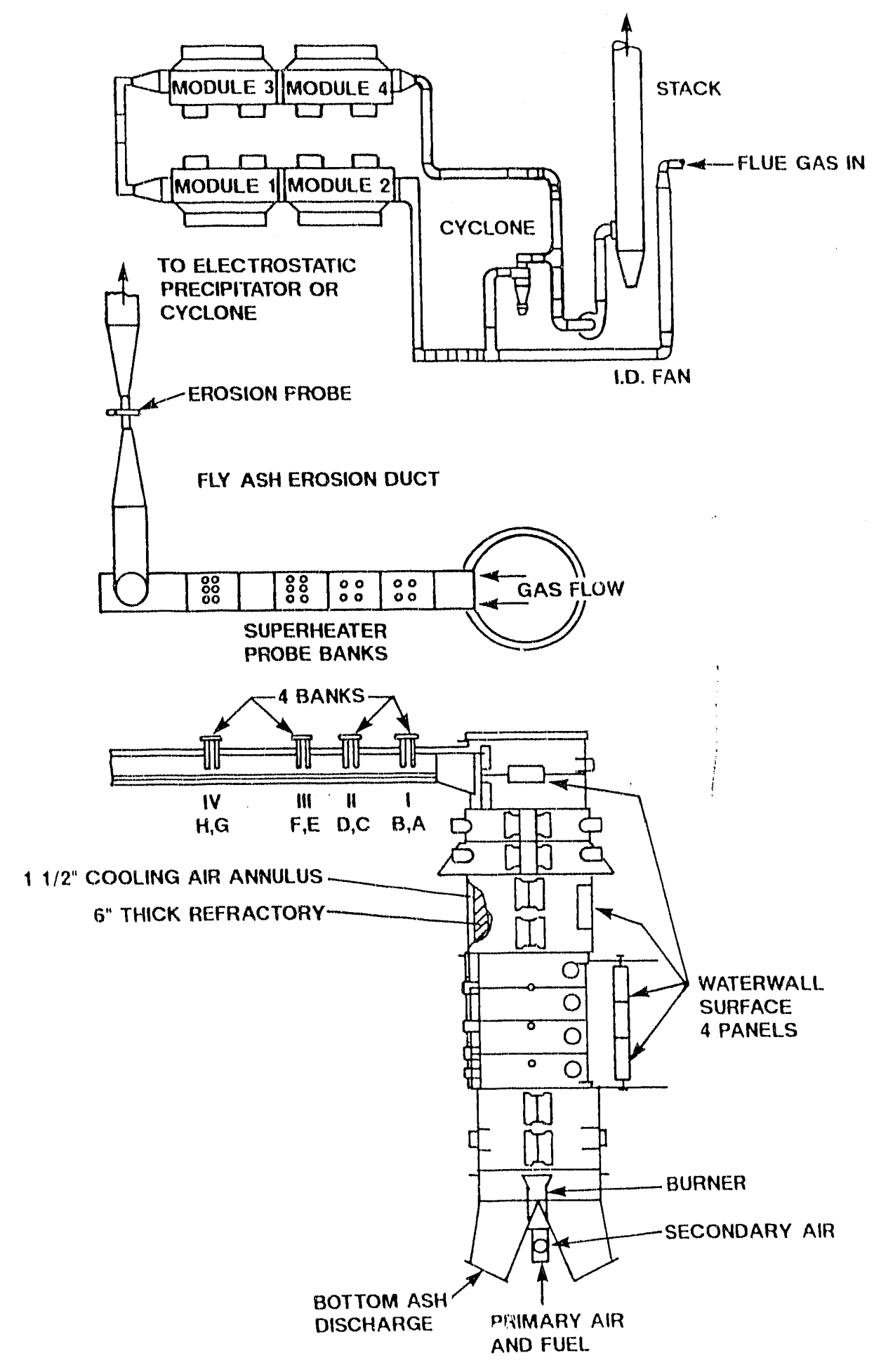

Figure 3.2.1 FIRESIDE PERFORMANCE TEST FACILITY 


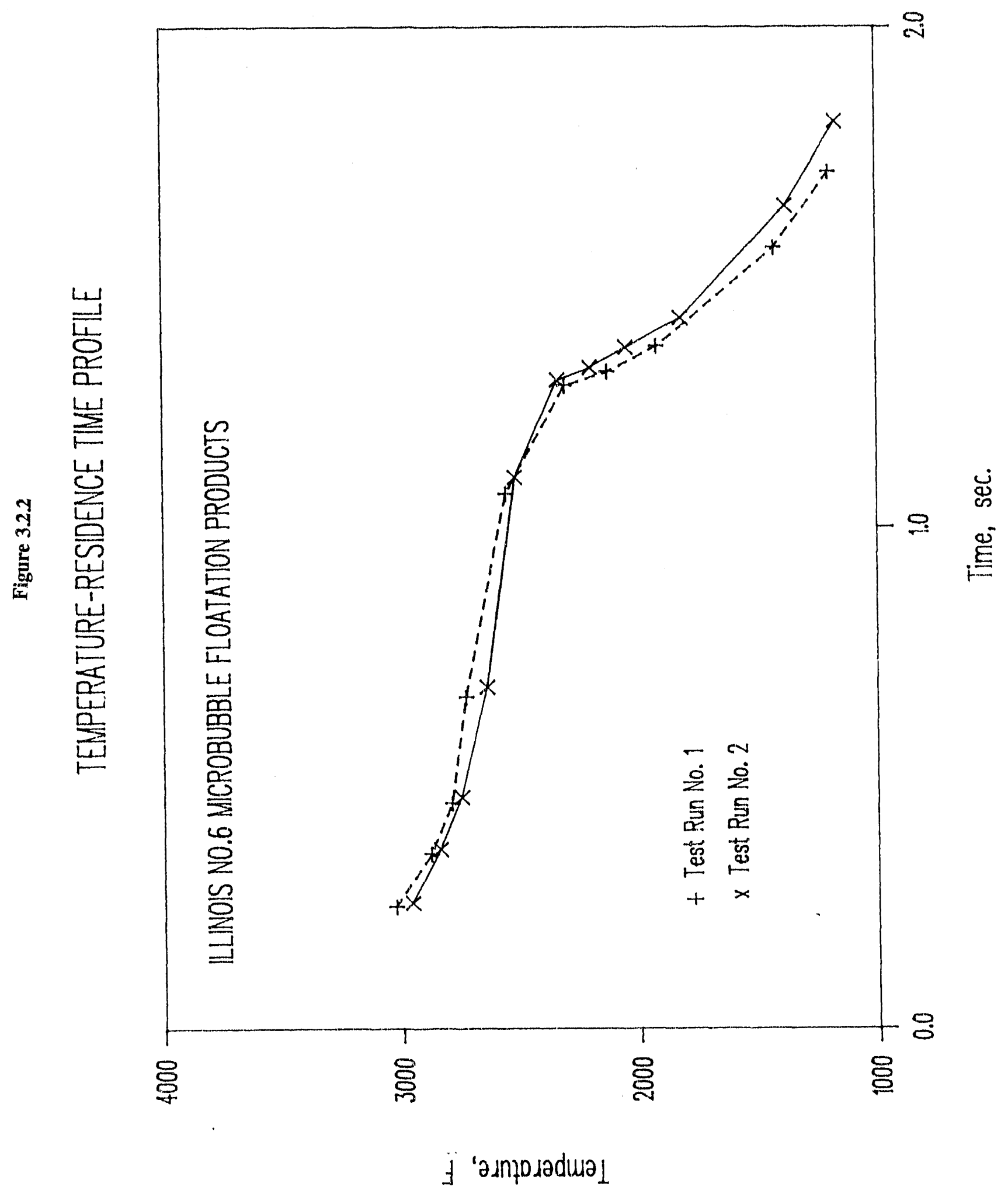


Table 1

ANALYSIS OF THE AS-FIRED AND MFP COALS

ILLINOIS NO. 6

As
Received
Received

Moisture
Received

Proximate (wt. \%)

Moisture

Volatile Matter

Fixed Carbon

Ash

Total

4.5
36.9
50.0
8.6
100.0

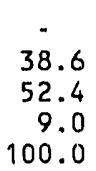

7.0

37.6

51.5

3.9

40.4

100.0

55.4

100.0

$\begin{array}{rr}4.5 & - \\ 4.7 & 5.0 \\ 66.1 & 69.3 \\ 2.9 & 3.0 \\ 1.3 & 1.3 \\ 11.9 & 12.4 \\ 8.6 & 9.0\end{array}$

$$
7.0
$$

4.5

70.3

2.5

0.9

10.9

3.9

100.0

Hydrogen

sulfur

Nitrogen

Oxygen

100.0

100.0

12100

7.1
6.9

12675

100.0

(1)

( $B+U /(b)$

Ib Ash/MBtu

Ib $\mathrm{SO}_{2} / \mathrm{MBtU}$

sulfur Forms (wt. \%)

Pyritic

Sulfate

Organic

0.5
0.3

0.3
2.1

12262

3.2

4.9

0.01

0.4

2.0

Ash Fusibility, Red. Atm. ( $\left.{ }^{\circ} \mathrm{F}\right)$

IDT

HT

HT

(FT-IT)

2000.0

2280.0

2420.0

2530.0

530.0

2020.0

2180.0

2230.0

2280.0

260.0

Ash Composition (wt. \%)

$$
\begin{aligned}
& { }_{\mathrm{A}}^{\mathrm{S}} \mathrm{l}^{\mathrm{O}} \mathrm{Z} \\
& { }_{\mathrm{Ca}} \mathrm{CaO}_{3}^{2} \\
& \mathrm{MgO} \\
& \mathrm{Na}_{2}{ }^{\mathrm{O}} \\
& \mathrm{K}_{2} \mathrm{O}^{2} \mathrm{O}_{2} \\
& \text { Total }
\end{aligned}
$$

51.7
20.7
15.9
2.2
0.9
0.5
2.0
6.8
2.1
97.8

42.0

19.3

21.2

3.7

1.4

2.3

2.3

2. 2

3.4

97.8 


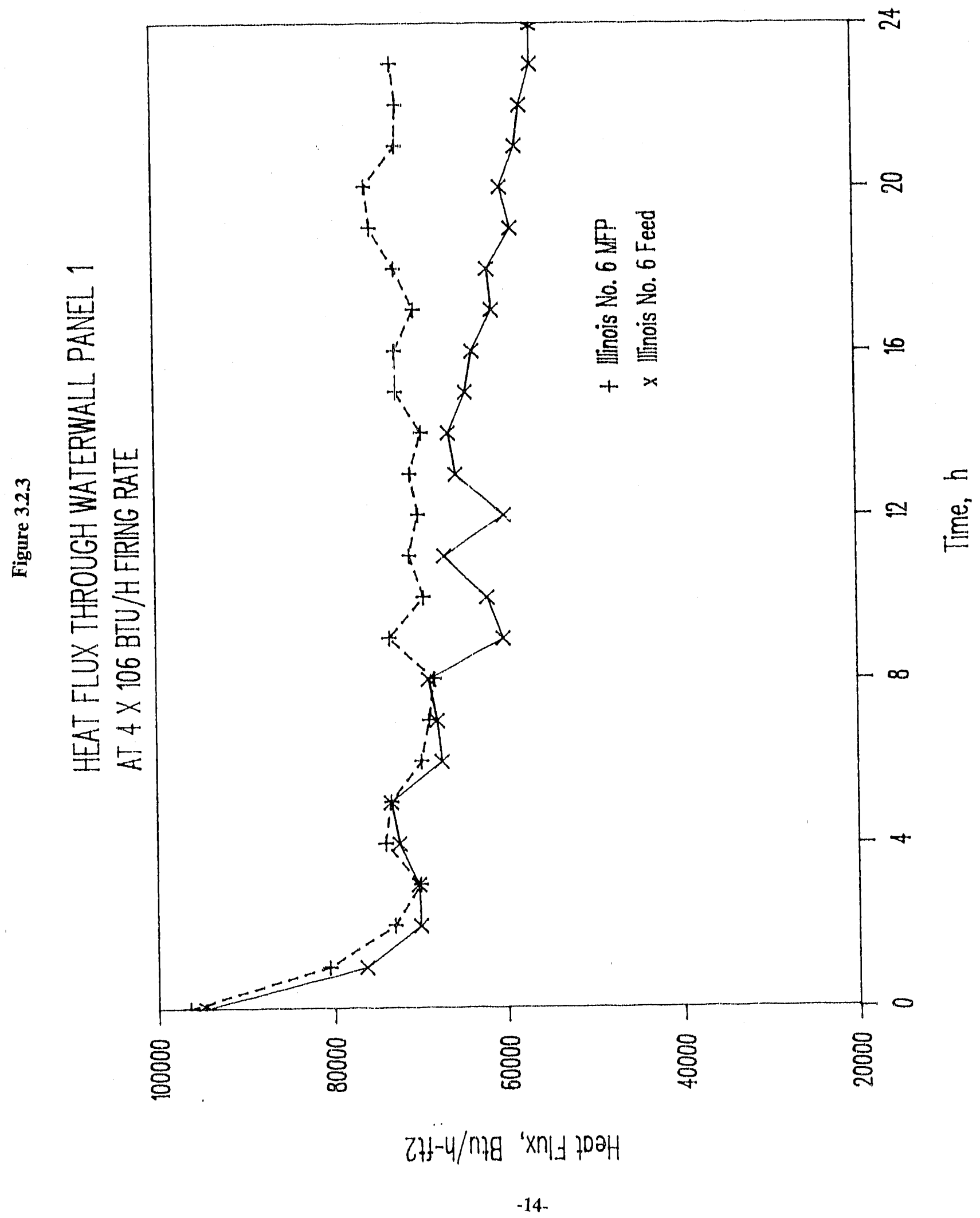


TABLE 2

WATERWALL DEPOSIT PHYSICAL CHARACTERISTICS

\begin{tabular}{|c|c|c|c|c|c|c|}
\hline $\begin{array}{l}\text { FUEL } \\
\text { TYPE }\end{array}$ & $\begin{array}{l}\text { FIRING } \\
\text { RATE } \\
\left(10^{\circ} \text { Btu/h) }\right.\end{array}$ & $\begin{array}{c}\text { FURNACE GAS } \\
\text { TEMPERATURE } \\
\left({ }^{\circ} \mathrm{F}\right) \\
\end{array}$ & $\begin{array}{l}\text { DEPOSIT } \\
\text { PHYSICAL } \\
\text { STATE } \\
\end{array}$ & $\begin{array}{l}\text { PANEL } \\
\text { COVERAGE } \\
\quad(8) \\
\end{array}$ & $\begin{array}{l}\text { DEPOSIT } \\
\text { THICKNESS } \\
\quad(\mathrm{mm}) \\
\end{array}$ & $\begin{array}{l}\text { DEPOSIT } \\
\text { CLEANABILITYY }\end{array}$ \\
\hline $\begin{array}{l}\text { ILL. } 6 \\
\text { FEED }\end{array}$ & 4.0 & 2980 & MOLTEN & 100 & 2.78 & POOR \\
\hline $\begin{array}{l}\text { ILL. } 6 \\
\text { MFP }\end{array}$ & 4.0 & 2960 & MOLTEN & 100 & 0.49 & POOR \\
\hline
\end{tabular}

TABILE 3

CONVECTION TUBE DEPOSIT PHYSICAL CHARACTERISTICS

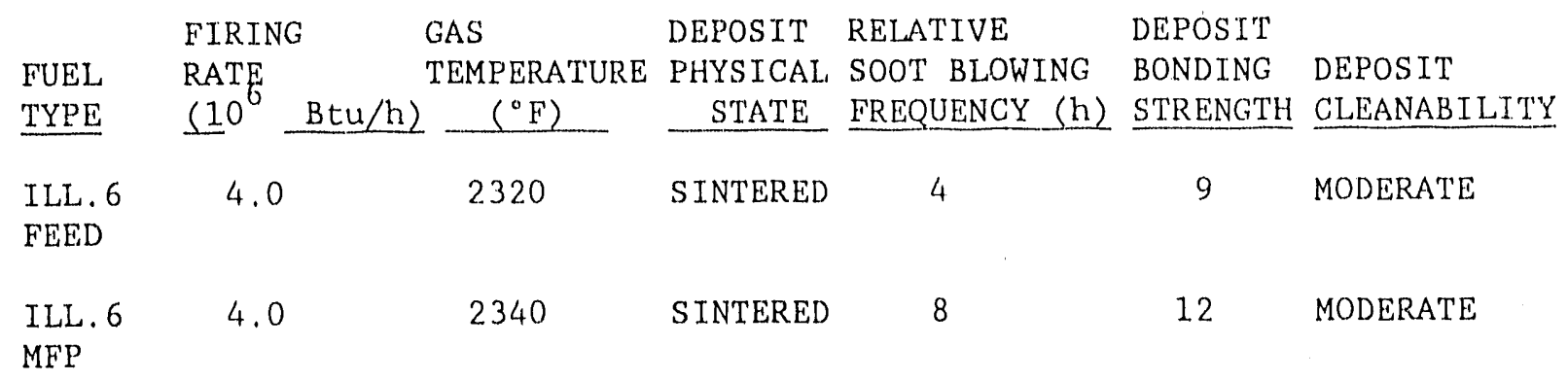




\section{Convection Pass Fouling Characterization}

Convection pass deposit characteristics were assessed by deposit buildup rate, deposit bonding strength, and deposit physical and chemical properties. The results obtained from the Illinois No. 6 feed and MFP fuels are summarized in Table 3.

In gencral, the convection pass deposit buildup rate was reduced with the MFP due to its lower ash loadings. The relative soot blowing frequency was reduced from approximately four hours for the feed coal to approximately eight hours for the MFP at a similar gas temperature range $\left(2320^{\circ} \mathrm{F}-2340^{\circ} \mathrm{F}\right)$. The in situ deposit bonding strengias were slightly higher with the MFP than with the feed coal but remained at moderate levels (deposit bonding strengths up to 15 are considered cleanable through conventional soot blowing).

The MFP also showed an unusual characteristic which was not observed with the feed coal and other conventional pulverized coals test-fired in the FPTF. Fine powdery deposits were developed at gas temperatures below $1500^{\circ} \mathrm{F}$ with the MFP. These powdery deposits adhered to the duct walls, the erosion probe, and the isokinetic sampling equipment downstream of the FPTF superheater sections. These observations would indicate that the MFP would present fouling problems in the economizer and airheater of steam generators.

The reasons for this phenomenon are not clear. Preliminary chemical analysis on the as-fired fuels showed that the MFP ash had lower ash fusibility temperatures and higher sodium contents than the feed coal ash (Table 1). The lower ash fusibility temperatures reflect mostly the changes in base-to-acid ratio due to the preferential removal of silicate mineral by the MF process. SEMPC analysis conducted by UNDEERC also showed that the MFP deposits had lower viscosity distributions than those found in the feed coal deposits (as discussed in more detail in Section 3.4). The MFP also generated more submicron fly ash particles than those from the feed coal (3.2 microns vs 7.5 microns mass mean diameter, respectively) (Figure 3.2.4). Each of these may have contributed to the fouling characteristics of the MFP. As the surface analysis data from the fly ash samples become available (currently being reduced by UNDEERC), it may help to further explain the fouling bchavior of the MFP.

\section{Fly Ash Erosion}

Fly ash erosion characteristics of the fuel were evaluated on line in a special high velocity convection section of the FPTF. A surface activation technique is used to determine metal loss on tube specimens after exposurc. This method measures the changes in intensity of radiation to determine erosion. The FPTF data is normalized to $60 \mathrm{ft} / \mathrm{sec}$ gas velocity and 10,000 hours exposure time to project field erosion rate potentials.

The FPTF results indicate crosion was reduced with the MFP. This was expected due to the reduced ash loading and quartz concentration, as well as generally smaller quartz particles in the MFP fly ash, compared to the feed coal.

\subsection{Electrostatic Precipitator Performancc}

Electrostatic precipitator performance characterization was conducted during the FPTF tests. Isokinetic sampling of the fly ash at both the inlet and outlet of the ESP, in situ fly ash resistivity, $\mathrm{SO}_{3}$ concentration and ESP power consumption were measured to determine the migration velocity and the overall ESP collection efficiency.

The ESP performance comparison between the Illinois No. 6 feed and MFP shows some marked differences. During Isokinetic sampling, the MFP fly ash tended to adhere to the collecting probe and created nozzle and filter blockage. No problem was encountered during the feed coal tests. In situ resistivity was an order of magnitude higher for the MFP than for the feed coal $\left(10^{13} \mathrm{ohm}-\mathrm{cm}\right.$ vs $\left.10^{12} \mathrm{ohm}-\mathrm{cm}\right)$. This was reflected in the 


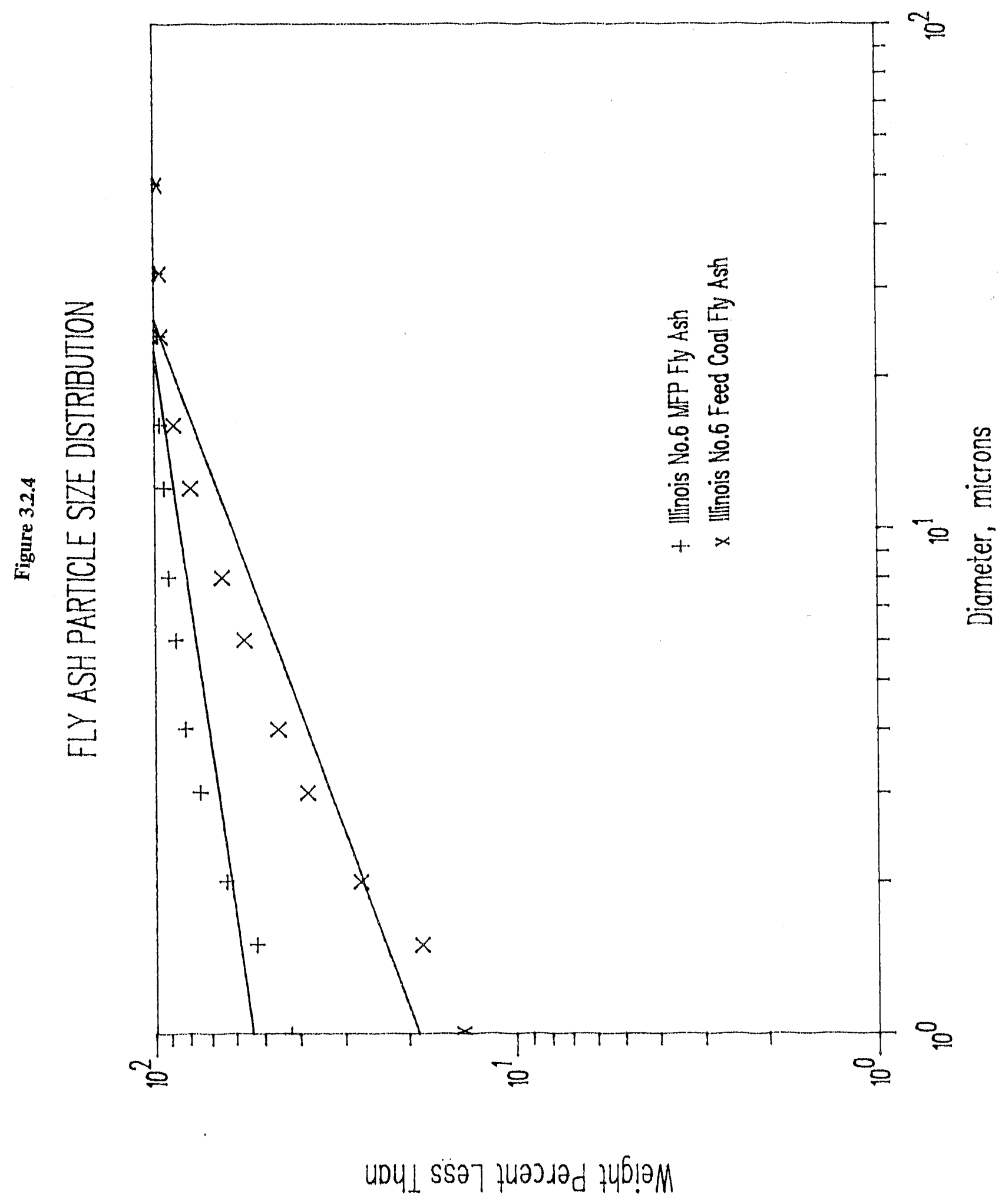


collection efficiency of the ESP, which was found to be minimal for the MFP (20 pereent) compared to the feed coal (90.4 percent). Migration velocity for the MFP was less than $1 \mathrm{~cm} / \mathrm{sec}$ as compared to $8 \mathrm{~cm} / \mathrm{sec}$ for the feed coal. Additional data reviews on fly ash particle size distribution and chemical composition, as well as bench-scale resistivity measurements, are on-going to help better understand the differences between the two Illinois fuels.

\subsection{Sample Analyses - UNDEERC}

All analyses of the FPTF samples from the combustion test of the Illinois feed and MFP coals were completed. The surface analysis data has not yet been reduced and will be discussed during the next reporting period.

In general, $x$-ray fluorescence analytical results show that there is little significant difference between the compositions of the two in-flame solids collected at the FPTF waterwall and furnace outlet and the fly ash sample collected downstream of the FPFT convection duct for cither the Illinois feed coal or MFP. With the exception for a slight enrichment in iron, sodium, and sulfur concentrations for the waterwall and supcrheater inner deposits, all other samples varied little from the composition of their respective as-fired fuel ash (Tables 4 and 5).

The crystalline phases present in the FPTF deposit samples as determined by $x$-ray diffraction are shown in Table 6. The major iron phases are maghemite (gamma $\mathrm{Fe}_{2} \mathrm{O}_{3}$ ) in the suspended solids samples, and hematite (alpha $\mathrm{Fe}_{2} \mathrm{O}_{3}$ ) in the deposits for either the Illinois No. 6 feed or' MFP. Comparison between the samples from the two fucls shows the presence of hercynite $\left(\mathrm{FeAl}_{2} \mathrm{O}_{4}\right)$ in the MFP samples but not in the feed coal samples, and the presence of mullite $\left(\mathrm{Al}_{6} \mathrm{Si}_{2} \mathrm{O}_{13}\right)$ in the feed coal samples but not in the MFP samples. These differences show that the MFP process has shifted the composition of the ash from the mullite to the hercynite phase ficld of the $\mathrm{FeOAl}_{2} \mathrm{O}_{3} \mathrm{SiO}_{2}$ system. the shift would indicate that the MFP ash particles can undergo melting within a deposit at lower temperatures than the feed coal ash particles.

Computer controlled scanning clectron microscopy (CCSEM) was used to determine composition vs size distribution of powder samples. The CCSEM data obtained from the in-flame solids waterwall, in-flame solids furnace outlet and fly ash samples show that iron-aluminosilicate and amorphous mincrals are the two major constituents in the deposit samples from either the feed or MFP fuel. The feed coal samples also show significant concentrations of quartz and aluminosilicate material, which could contribute to higher crosion due to their high hardness factors.

The scanning electron microscopy point count (SEMPC) technique was also used to mcasure the variations in composition within an ash deposit. The composition data is then used to calculate the viscosity distribution within a deposit using a modified Urbain equation. The results in Figures 3.4.1, 3.4.2, and 3.4.3 show that the MFP deposits have lower calculated viscosity distributions than the feed coal deposits. The lower melting MFP would tend to form more highly sintered deposits than the feed coal. These results were in general agreement with those observed during the FPTF MFP testing. However, the differences between the deposits generated from the MFP and feed coal were not as significant as indicated by the SEMPC data. 
TABLE 4

XRF ANALYSES OF ILLINOIS NO. 6 MICROBUBBLE CLEANED FPTF WATERWALL DEPOSITS (WT \%)

\begin{tabular}{lcc}
\hline $\mathrm{OXIDE}$ & Pand 1 & Pand 4 \\
\cline { 2 - 3 } $\mathrm{SiO}_{2}$ & 40.0 & 40.0 \\
$\mathrm{Al}_{2} \mathrm{O}_{3}$ & 18.1 & 18.4 \\
$\mathrm{Fe}_{2} \mathrm{O}_{3}$ & 23.2 & 24.7 \\
$\mathrm{TiO}_{2}$ & 2.4 & 2.7 \\
$\mathrm{P}_{2} \mathrm{O}_{5}$ & 0.3 & 0.3 \\
$\mathrm{CaO}$ & 4.0 & 3.5 \\
$\mathrm{MgO}$ & 1.3 & 1.4 \\
$\mathrm{Na}$ & 2.0 & 1.6 \\
$\mathrm{~K}_{2} \mathrm{O}$ & 4.1 & 3.3 \\
$\mathrm{SO}_{3}$ & 4.6 & 4.1 \\
$\mathrm{Closure}$ & & 98.1 \\
\hline
\end{tabular}

TABLE 5

XRF ANALYSES OF ILLINOIS NO. 6 MICROBUBBLE-CLEANED FPTF STEAM TUBE DEPOSITS (WT \%)

\begin{tabular}{|c|c|c|c|c|}
\hline \multirow[b]{2}{*}{ OXIDE } & \multicolumn{2}{|c|}{ TUBE $1 \mathrm{~A}$} & \multicolumn{2}{|c|}{ TUBE IIC } \\
\hline & Inner & Outer & Inner & Outer \\
\hline $\mathrm{SiO}_{2}$ & 41.7 & 46.9 & 38.4 & 44.6 \\
\hline $\mathrm{Al}_{2} \mathrm{O}_{3}$ & 18.0 & 20.6 & 17.8 & 20.9 \\
\hline $\mathrm{Fe}_{2} \mathrm{O}_{3}$ & 23.3 & 19.7 & 24.3 & 21.5 \\
\hline $\mathrm{TiO}_{2}$ & 2.2 & 2.3 & 2.4 & 2.5 \\
\hline $\mathrm{P}_{2} \mathrm{O}_{5}$ & 0.2 & $<0.2$ & 0.3 & $<0.2$ \\
\hline $\mathrm{CaO}$ & 5.4 & 5.8 & 5.8 & 5.0 \\
\hline $\mathrm{MgO}$ & 1.2 & 1.0 & 1.2 & 1.4 \\
\hline $\mathrm{Na}_{2} \mathrm{O}$ & 1.1 & 1.0 & 1.4 & 1.1 \\
\hline $\mathrm{K}_{2} \mathrm{O}$ & 2.5 & 2.7 & 2.5 & 2.7 \\
\hline $\mathrm{SO}_{3}$ & 4.4 & $<0.5$ & 5.8 & $<0.5$ \\
\hline Closure & 99.1 & 94.3 & 99.8 & 96.1 \\
\hline
\end{tabular}


TABLE 6

CRYSTALLINE SPECIES IDENTIFIED BY XRD IN THE ILLINOIS

NO. 6 MICROBUBBLE-CLEANED COAL FPTF SAMPLES

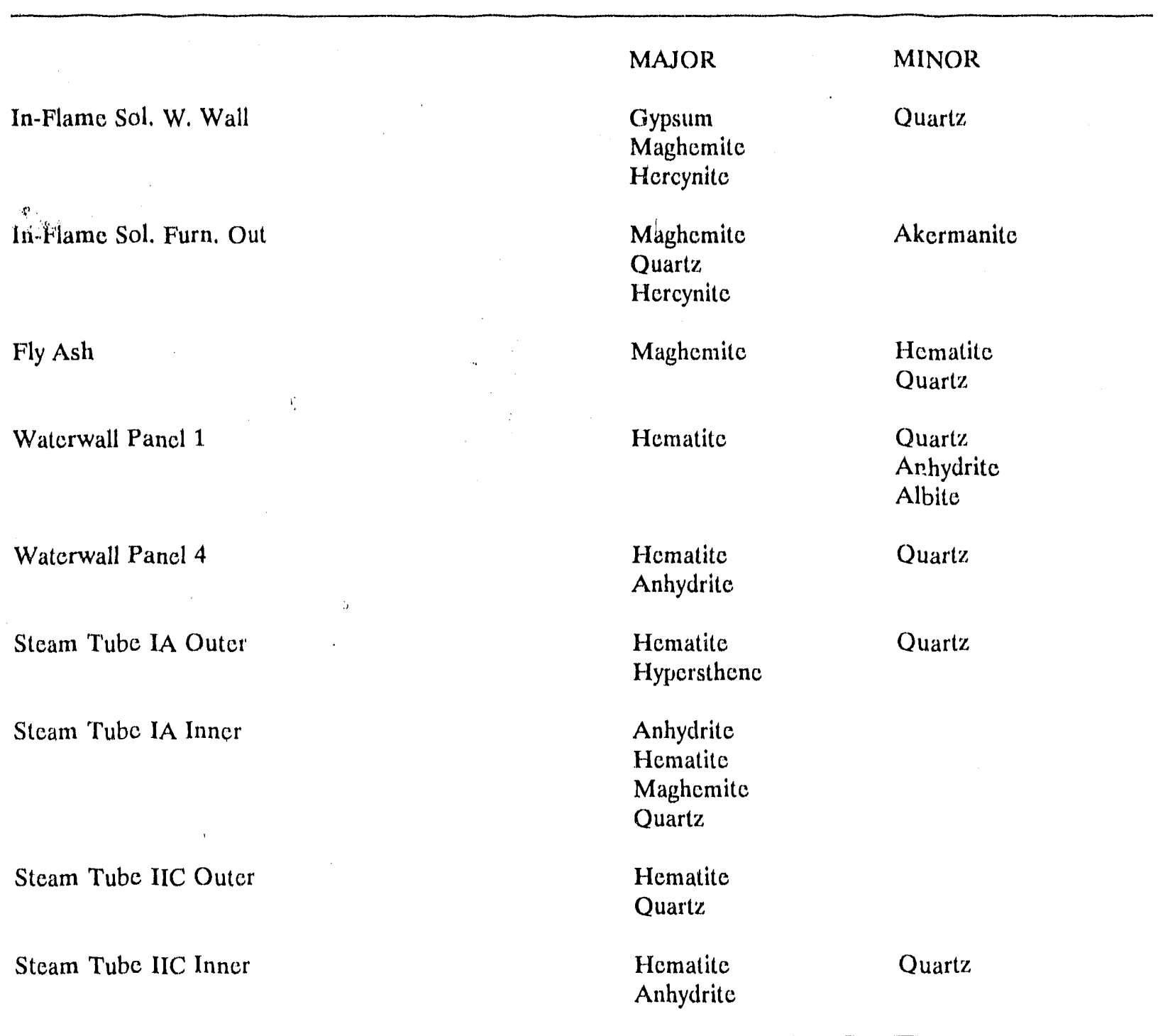




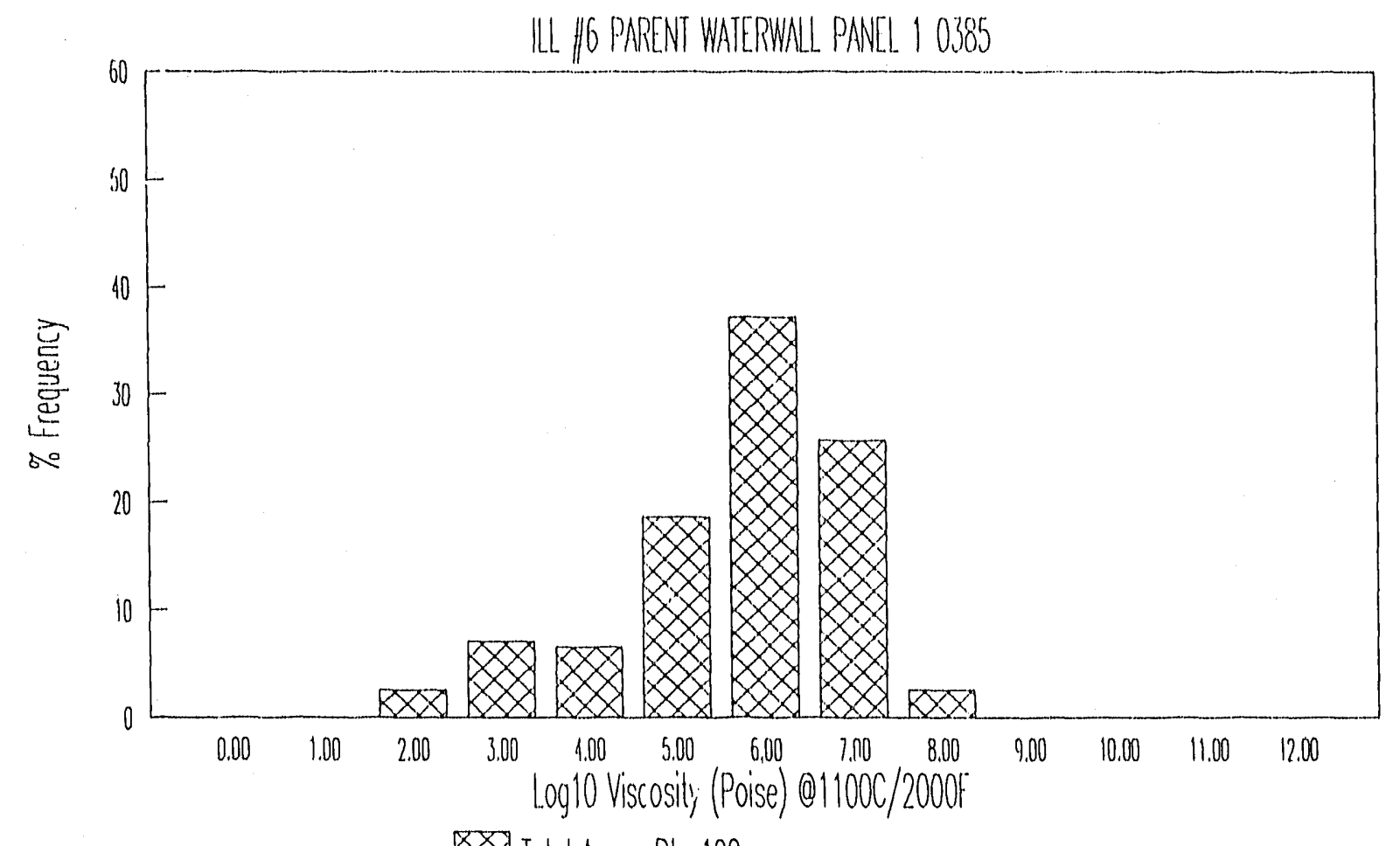

Total Amor. Pts 199

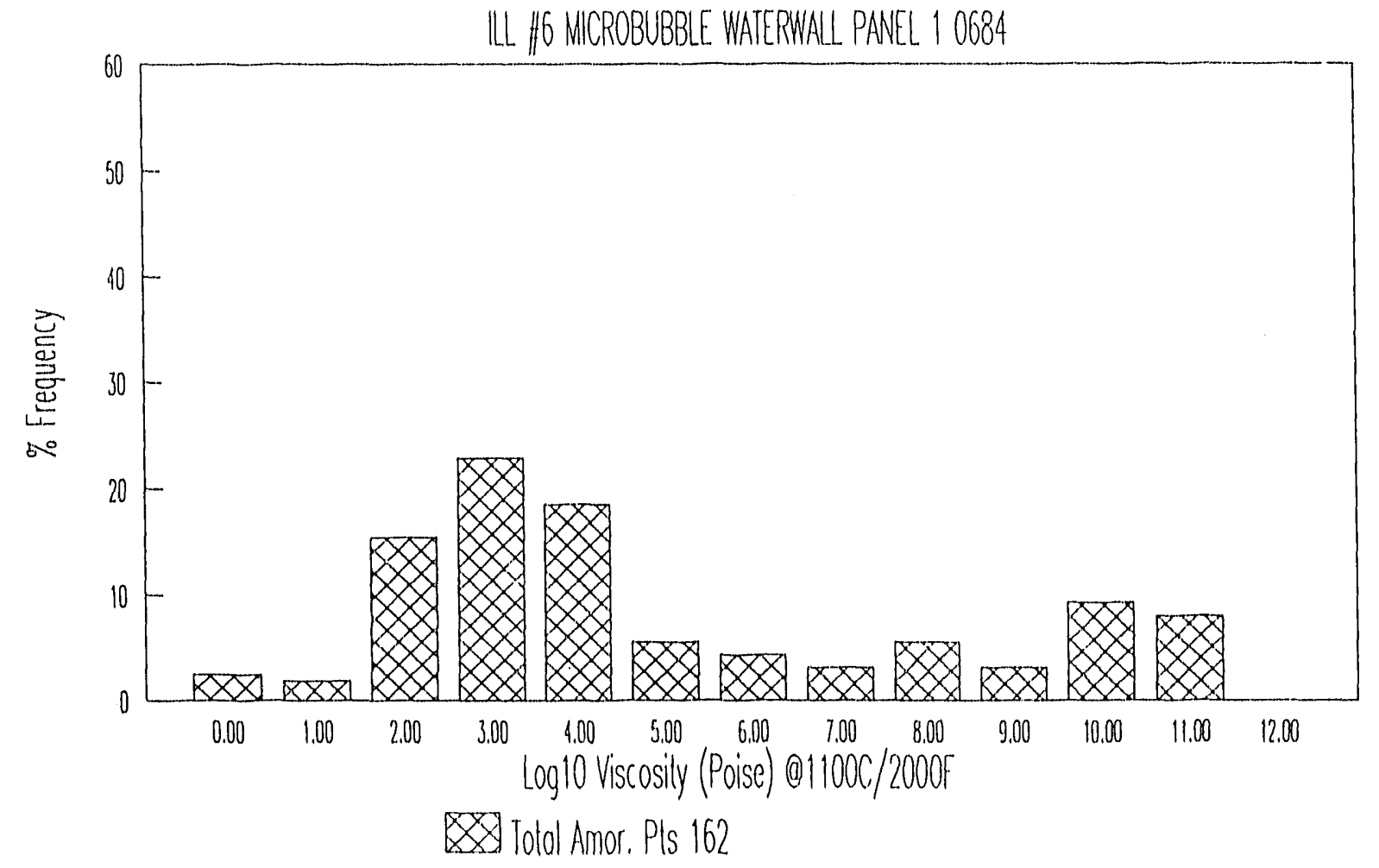

Figure 3.4.1 The calculated viscosity distributions for the Illinois No. 6 parent (top) and cleaned (bottom) waterwall panel 1 samples. 

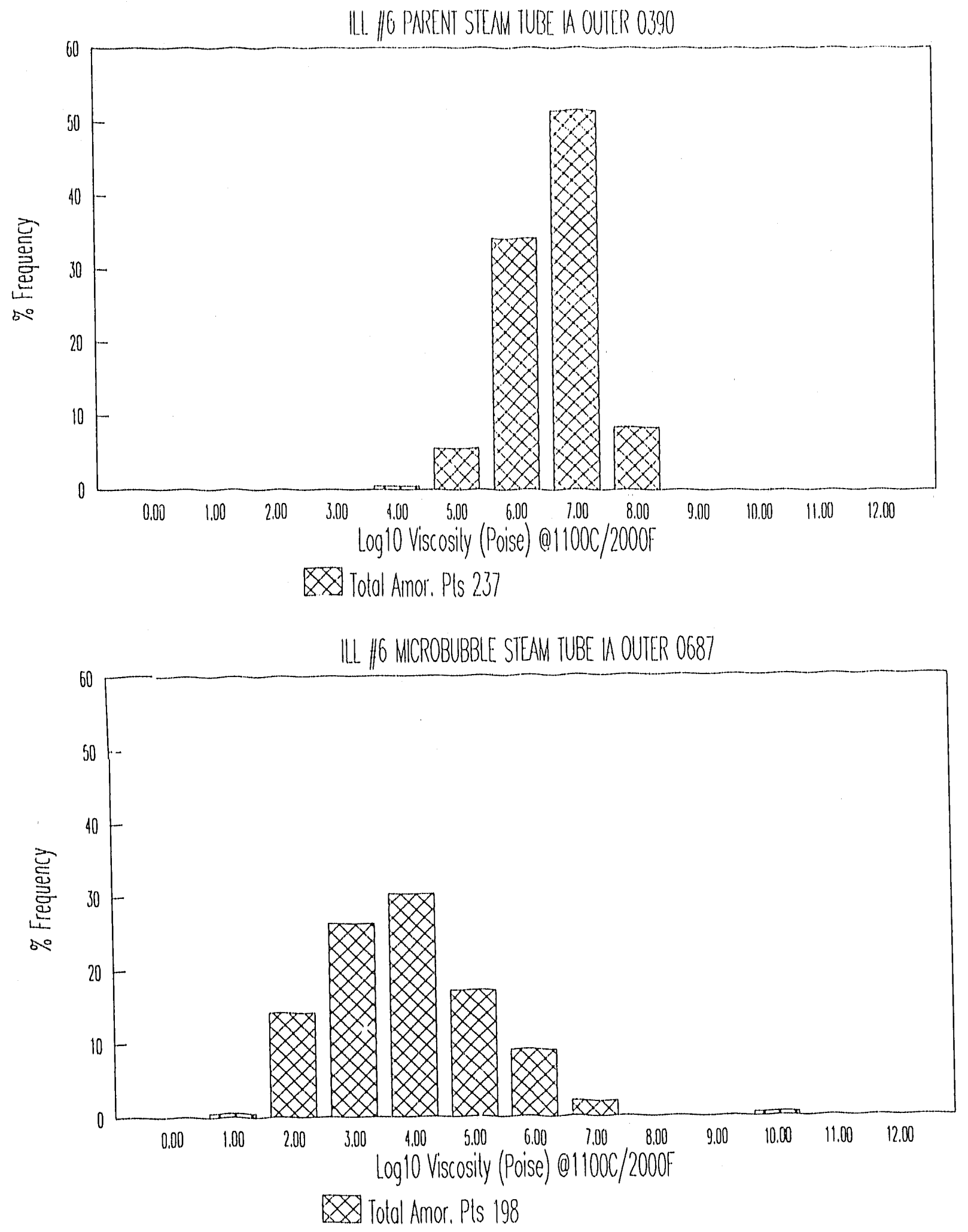

Figure 3.4.2 The calculated viscosity distributions for the Illinois No. 6 parent (top) and cleaned (bottom) steam tube IA outer sinter layer samples. 

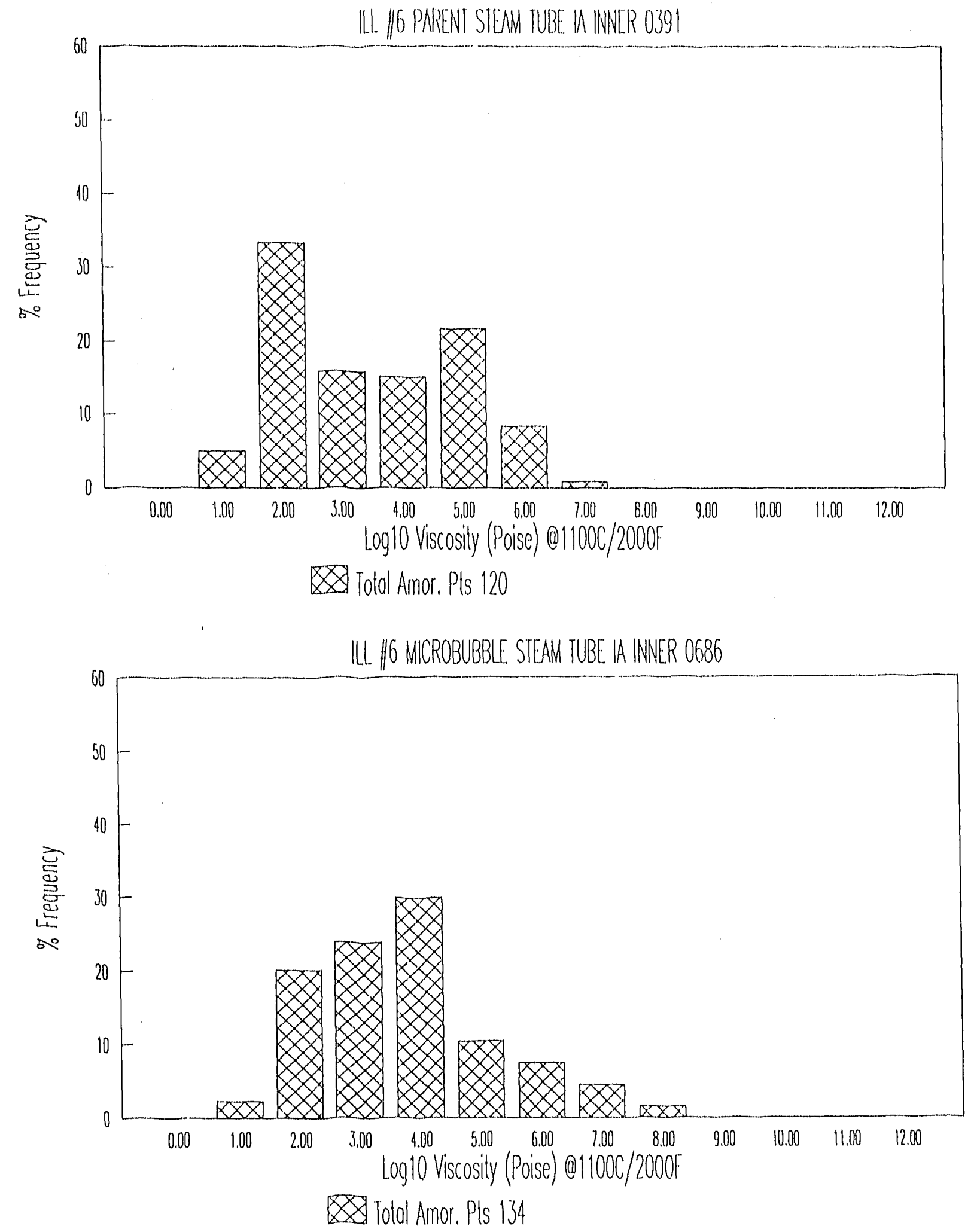

Figure 3.4.3 The calculated viscosity distributions for the Illinois No. 6 parent (top) and cleaned (bottom) steam tube IA inner powder layer sample. 
TASK 4 - SCALE-UP TESTS

The purpose of the scale-up tests is to verify that the results obtained from tests done at bench and pilot scales in Tasks 2 and 3 can be used to provide reasonable estimates of the performance effects when firing BCFs in commercial-scale boilers. Two beneficiated fuels will be fired in either a small utility boiler or a full-scale test furnace.

The only activities in this task were discussions on fuel procurement, alternative test facility selection, and scheduling. Recommendations were submitted to the DOE.

\section{TASK 5 - TECHNICAL-ECONOMIC EVALUATIONS}

The results of bench-scale, pilot-scale, and scale-up tests (Tasks 2, 3, and 4) are used to predict the performance of three commercial boilers. The boilers include: a $560 \mathrm{MW}$ coal-designed utility unit; a $600 \mathrm{MW}$ oil-designed utility unit; and an $80,000 \mathrm{lb} / \mathrm{hr}$ oil-designed, shop-assembled industrial unit. Eight of the base project BCFs are used in models of each unit to calculate performance.

The writing of a report describing the commercial boilers which will be evaluated continued. 


\section{WORK PLANNED FOR NEXT QUAR'TER}

- Prepare Upper Freeport and Pittsburgh No. 8 MFPs for testing; the former as CWF and the latter as dry pulverized fuel.

- Process Upper Freeport spherical agglomeration product for testing as dry pulverized fucl.

- Continue standard bench-scale tests.

- Continue drop tube furnace tests at CE and MIT.

- Test Upper Freeport MFP CWF in MIT's CRF.

- Test Upper Freeport and Pittsburgh No. 8 BCF's in CE's FPTF.

- Complete report describing the Task 5 boilers. 

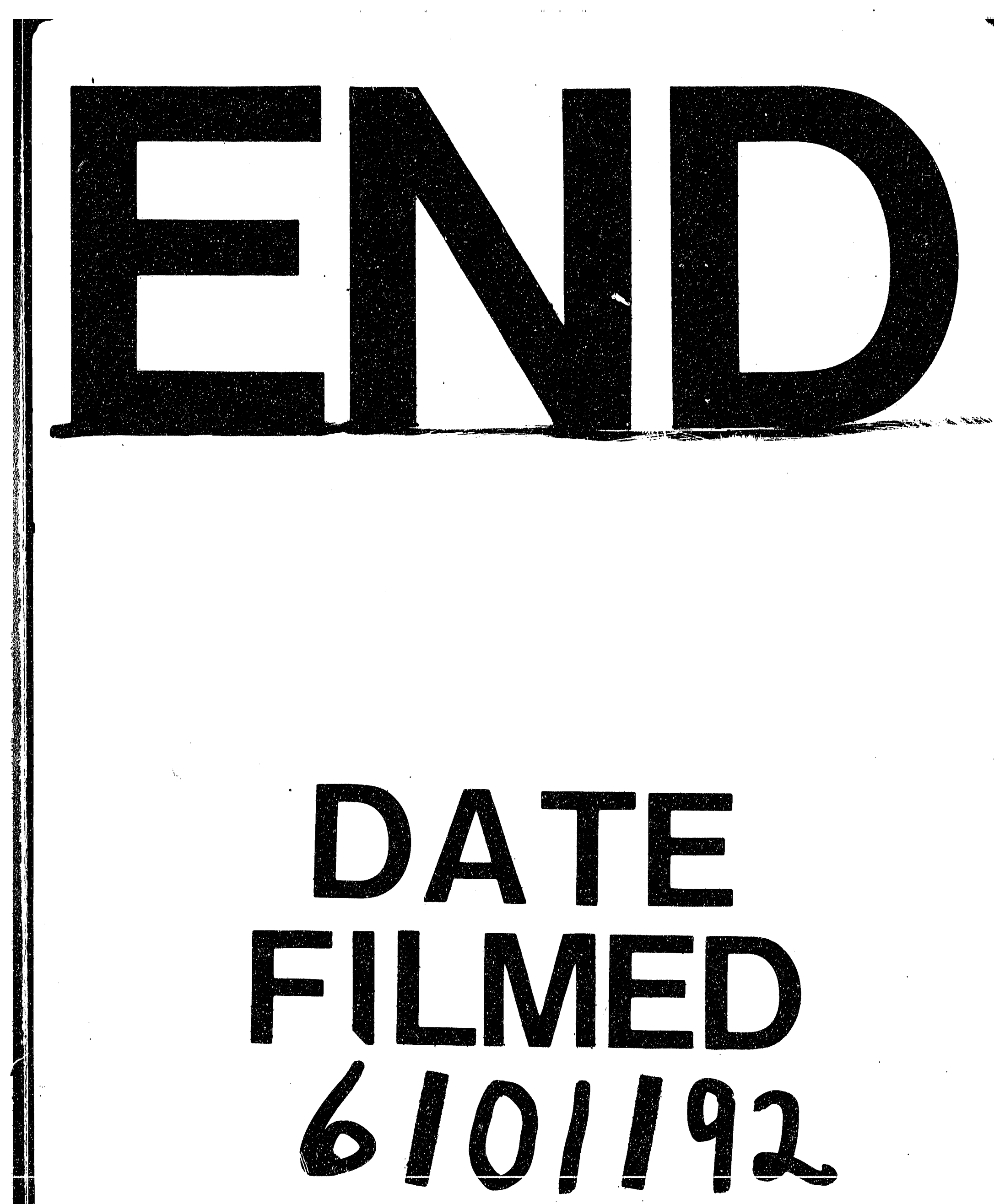


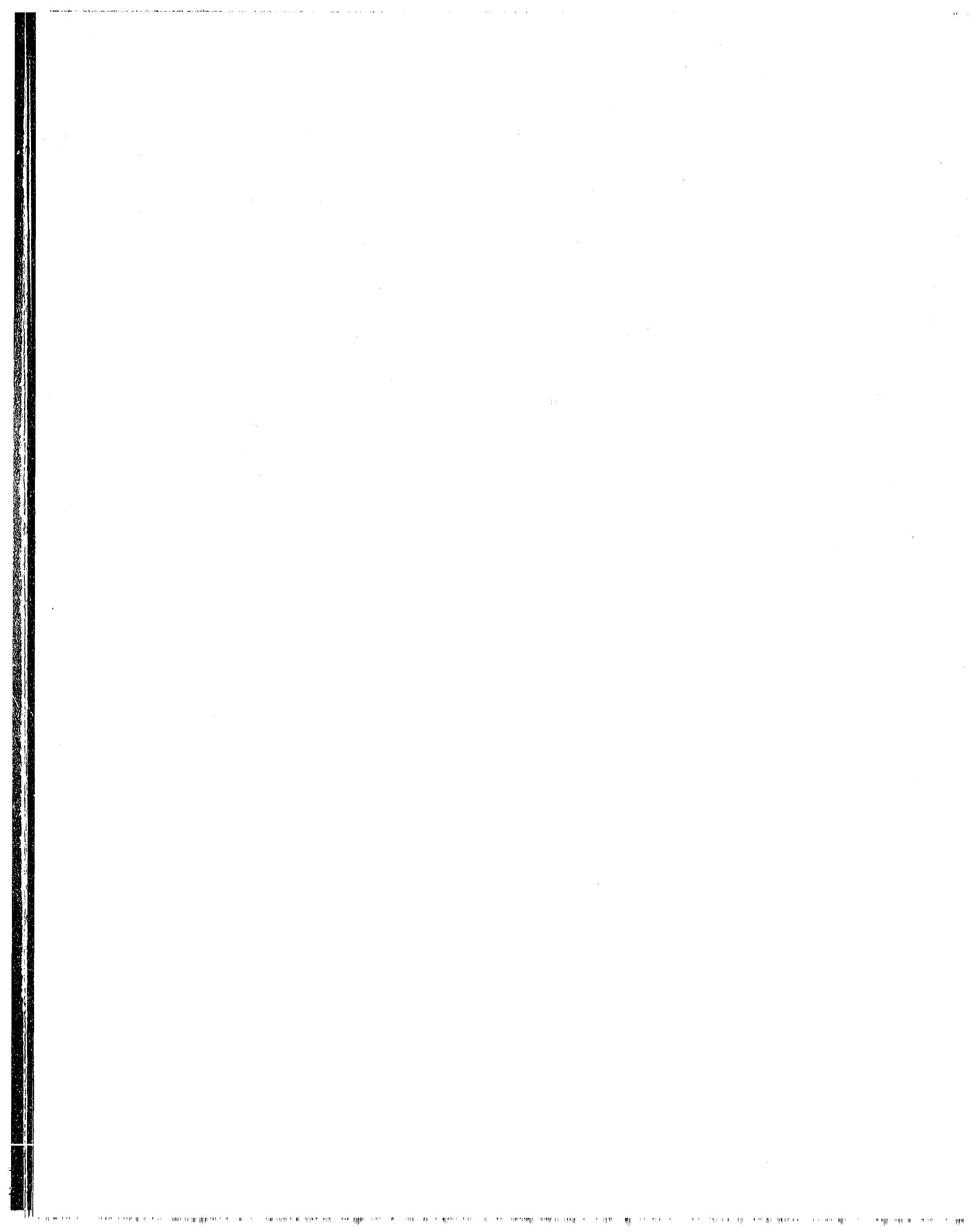

